\title{
Oral Nifedipine versus Intravenous Labetalol for Acute Blood Pressure Control in Severe Hypertension of Pregnancy: A Study at Faridpur Medical College Hospital
}

\author{
SK Biswas ${ }^{1}$, SK Raha ${ }^{2}$, Mahbuba $^{3}$
}

\begin{abstract}
:
The first line antihypertensive treatment for severe hypertension of pregnancy includes labetalol, hydralazine, or nifedipine. Rapid but safe blood pressure control allows the definitive treatment, the delivery of baby to be carried out with minimal delay and good maternal and fetal outcomes. This non-randomized clinical trial was performed in Faridpur Medical College Hospital to compare the effectiveness and tolerability of oral nifedipine and intravenous labetalol in the acute control of severe hypertension of pregnancy. Total 50 admitted pregnant women with a viable fetus ( $\geq 24$ weeks of gestation) having severe hypertension were allocated into two groups, Group A: 25 patients receiving oral nifedipine (10 mg), Group B: 25 patients receiving injectable labetalol (with incremental doses: 20, 40, $80 \mathrm{mg})$. Up to 5 doses were tried for each drug at 15 minutes interval until target blood pressure $(\leq 150 / 100 \mathrm{mmHg})$ was achieved. Baseline characteristics like mean age, mean weight, heart rate, systolic and diastolic pressures were similar in both labetalol and nifedipine groups. The average time required to achieve target blood pressure was 30.33 \pm 10.44 minutes for labetalol and $25.63 \pm 10.12$ minutes for nifedipine $(\mathrm{p}=0.9129)$. Feto-maternal outcomes and adverse drug related effects were similar among the two groups. Both intravenous labetalol and oral nifedipine were found to be equally effective and well tolerated. Nifedipine may be preferable as it is a simple, flat dose schedule and an oral regimen.
\end{abstract}

Key words: Hypertension of pregnancy, Hydralazine, Nifedipine, Labetalol, Target blood pressure.

\section{Introduction:}

Hypertension is one of the common medical complications of pregnancy and contributes significantly to maternal and perinatal morbidity and mortality. ${ }^{1}$ Hypertension in pregnancy is a special condition because the duration of therapy is shorter, the benefits to the mother may not be obvious during the short time of treatment and the exposure to drugs regards both mother and fetus. Even if the delivery is the only treatment and it leads to the disappearance of the diseases, this is usually problematic below

1. Dr. Smriti Kana Biswas, MBBS, FCPS (Gynaecology and Obstetrics), Medical Officer, 250 Bedded TB Hospital, Shyamoli, Dhaka.

2. Dr. Sanjay Kumar Raha, MBBS, MS (Cardiovascular and Thoracic Surgery), Associate Professor, Department of cardiac surgery, NICVD, Dhaka

3. Dr. Mahbuba, MBBS, FCPS (Gynae \& Obs), Professor, Department of Obstetrics and Gynaecology, Sheikh Sayera

Address of correspondence :

Dr. Smriti Kana Biswas, MBBS, Medical Officer, 250 Bedded TB

Hospital, Shyamoli, Dhaka-1207. Phone: +88-01716529240,

E-mail: drsmritikanabiswas83@gmail.com
28 weeks of gestation when the baby can be expected to be extremely immature. In addition, the pathophysiology of the hypertensive disorders in pregnancy will have different effects on the pharmacokinetics as well as the pharmacodynamics of the drugs used ${ }^{2}$. National Institute for health and Clinical Excellence, UK, recommends inpatient treatment of severe hypertension of pregnancy with labetalol (oral or intravenous), intravenous hydralazine, or oral nifedipine as the first line alternative antihypertensive within the critical care setting ${ }^{3,4}$.

Hypertensive emergency (crisis) is characterized by a severe elevation in blood pressure $(>180 / 120 \mathrm{~mm} \mathrm{Hg})$ complicated by evidence of impending or progressive target organ dysfunction (specially central nervous system, cardiovascular system and or the renal system) ${ }^{3}$. The National Institute of Health and Clinical Excellence UK, 2010 guidelines define gestational hypertension is severe when systolic blood pressure (SBP) is $\geq 160 \mathrm{~mm} \mathrm{Hg}$ or diastolic blood pressure (DBP) is $\geq 110 \mathrm{~mm} \mathrm{Hg}$, and recommend keeping SBP below $150 \mathrm{mmHg}$ and DBP between 80 and $100 \mathrm{mmHg}$ for women with severe hypertension in critical care ${ }^{4}$. 
The hypotensive effect of the peripheral vasodilator, hydralazine occurs within 5-20 minutes. Maximum effect occurs between 10-80 minutes and the duration of action is 2-6 hours ${ }^{5,6}$. A meta-analysis comparing hydralazine against other antihypertensive agents for severe hypertension in pregnancy has indicated that hydralazine is associated with more maternal hypotension, caesarean sections, placental abruption, maternal oliguria and adverse effects on fetal heart rate $^{3}$.

Labetalol is a non-selective beta adrenergic receptor blocking agent, producing dose-related falls in blood pressure without significant reduction in heart rate. Onset of action of intravenous labetalol is at five minutes. Peak effect occurs at 10-15 minutes and the duration of action is 45 minutes to six hours. A fluid preload is advised to counteract the potential for a sudden decrease in blood pressure ${ }^{6,7}$.

Nifedipine is a calcium channel blocker. After oral administration, the onset of action is 1.5 to 4.5 hours. Administration of the tablet results in a half-life of about 6 to 12 hours. The pharmacological action of nifedipine persists for up to 12 hours after administration of the tablet. Caution should be used in patients with impaired liver function ${ }^{6,8}$.

It is a common practice to stabilize severe maternal hypertension prior to delivery either by labour induction or cesarean section to avoid dangerous fluctuations or exacerbations of blood pressure during labour or anaesthesia. Hence speedy but safe blood pressure control will allow the definitive treatment of delivery of the baby to be carried with minimal delay in many cases of severe hypertension in late pregnancy ${ }^{3}$.

In this study 50 pregnant patients with sustained severe hypertension were selected purposively. Of them, 25 patients received oral nifedipine (10mg each) and other 25 received injectable labetalol. The aim of the study was to determine the safety and efficacy of antihypertensive agents- nifedipine and labetalol in the acute blood pressure control in the setting of hypertensive emergencies of pregnancies.

\section{Materials and Methods:}

This non-randomized clinical trial was performed in the department of obstetrics and gynaecology, Faridpur Medical College Hospital during the period of September 2013 to February 2014. Total 50 admitted pregnant women with a viable fetus $(\geq 24$ weeks of gestation) and sustained severe hypertension were purposively selected and equally allocated in two groups, Group A: 25 patients receiving oral nifedipine, Group B: 25 patients receiving injectable labetalol. Patients with essential hypertension, eclampsia, known case of heart diseases, bronchial asthma, diabetes mellitus, haematological disorder, hepatic and renal impairment, exposure to either study drugs in 24 hours of enrollment, history of allergy to labetalol or nifedipine and maternal heart rate $<60$ or $>120$ beats per minute were excluded from the study.

Each of the Group A patients received $10 \mathrm{mg}$ of oral nifedipine. The same dose was repeated at 15 minutes interval until target blood pressure (SBP below 150 $\mathrm{mmHg}$ and DBP between 80 and $100 \mathrm{mmHg}$ ) was achieved. Group B patients received injectable labetalol (with incremental doses: 20, 40, $80 \mathrm{mg}$ ) at 15 minutes interval until target blood pressure was achieved. Up to 5 doses were tried for each drug. After failure of first one the opposite one was chosen and tried up to 5 doses. When target blood pressure was achieved or when trial of both drugs were failed the usual unit protocol was followed. If patient developed hypotension $\mathrm{BP} \leq 90 / 60 \mathrm{mmHg}$ then the trial was terminated and patients were treated with intravenous fluids and ephedrine. If any patient developed bradycardia $(<60$ beats/minutes), the trial was terminated and patient was treated with atropine /epinephrine.

Demographic and standard laboratory data were collected on admission. During the study period maternal blood pressures were recorded at every fifteen minutes interval till first 30 minutes after achieving target blood pressure, then every thirty minutes for next 2 hours then hourly. Continuous maternal vital parameters and electronic fetal monitoring were done. Cardiotocographic (CTG) tracing were taken at the beginning, then two hourly and then one at the end of the study.

Our primary outcome variable was the time (minutes) taken to achieve target blood pressure $\leq 150 / 100$ $\mathrm{mmHg}$. Secondary outcome variables were total antihypertensive doses to achieve target blood pressure, crossover to alternative antihypertensive, management at the end of trial: expedited delivery/ expectant, mode of delivery: caesarean or vaginal, 5 minutes Apgar Score $<7$, maternal intensive care admission, neonatal intensive care admission, reported side effects e.g. nausea, vomiting, dizziness, palpitations, headache etc. 
Data were collected using a structured questionnaire containing all the variables of interest. Statistical analyses were carried out by using the Statistical Package for Social Sciences version 16.0 for Windows (SPSS Inc., Chicago, Illinois, USA).

\section{Results:}

Table I shows the baseline characteristics of the study sample. The age range for both groups was 20-34 years. The mean ages for Nifedipine and Labetalol groups were similar ( $\mathrm{p}$ value $=0.54 ;>0.05$ ). Most patients of both Labetalol $(60 \%)$ and Nifedipine $(56 \%)$ groups were within 50-60 kilograms weight range. The mean weights were not statistically different ( $\mathrm{p}$ value $=0.61$; $>0.05$ ). The systolic blood pressures (SBP) range for both groups was 161-195 mmHg. The mean SBPs were statistically similar ( $p$ value $=0.8971 ;>0.05)$. About $72 \%$ of group A and $76 \%$ of group B patients had diastolic blood pressures (DBP) within 111-120 mmHg. The DBP range for both groups was 105-121 mmHg. However, the mean diastolic blood pressures (DBP) were not statistically different ( $\mathrm{p}$ value $=0.7335 ;>0.05$ ). Around $44 \%$ patients of group A had heart rates within 91-100 beats/minutes. On the other hand 36\% patients of group B had heart rates within 81-90 beats/minutes. The mean heart rates were also statistically different ( $p$ value $=0.8392 ;>0.05)$.

Table-I: Baseline Characteristics of Patients $(\mathrm{n}=50)$

\begin{tabular}{|c|c|c|c|}
\hline $\begin{array}{l}\text { Baseline } \\
\text { Characteristics }\end{array}$ & $\begin{array}{l}\text { GroupA } \\
\text { (Nifedipine) } \\
(n=25)\end{array}$ & $\begin{array}{l}\text { GroupB } \\
\text { (Labetalol) } \\
(\mathrm{n}=25)\end{array}$ & $\overline{p \text { value }}$ \\
\hline Age (years, mean $\pm S D$ ) & $25.52 \pm 3.5$ & $26.16 \pm 3.8$ & $0.54^{\text {ns }}$ \\
\hline $\begin{array}{l}\text { Maternal Weight (kg, } \\
\text { mean } \pm S D)^{\#}\end{array}$ & $56.24 \pm 9.5$ & $56.96 \pm 7.3$ & $0.61^{\text {ns }}$ \\
\hline $\begin{array}{l}\text { On admission Systolic } \\
\text { Blood Pressure } \\
(\mathrm{mmHg} \text {, mean } \pm \mathrm{SD})^{\#}\end{array}$ & $171.8 \pm 8.4$ & $171.08 \pm 8.1$ & $0.8971^{\text {ns }}$ \\
\hline $\begin{array}{l}\text { On admission } \\
\text { Diastolic Blood } \\
\text { Pressure (mmHg, }\end{array}$ & $111.24 \pm 5.4$ & $112.88 \pm 8.8$ & $0.7335_{n s}$ \\
\hline $\begin{array}{l}\text { mean } \pm S D)^{\#} \\
\text { Maternal heart } \\
\text { rate (beats/min, mea }\end{array}$ & $\begin{array}{l}86.4 \pm 10.1 \\
\text { SD) }\end{array}$ & $86.24 \pm 10.7$ & $0.8392^{\text {ns }}$ \\
\hline
\end{tabular}

\# Student's t - Test, ns= non-significant.

Table II shows that 15 minutes after administration $6(24 \%)$ patients of nifedipine and $4(16 \%)$ patients of labetalol group achieved target blood pressure. After 30 minutes total $16(64 \%)$ of nifedipine group and 12 $(48 \%)$ of labetalol group achieved target blood pressure. After 45 minutes total $22(88 \%)$ of nifedipine group and $19(76 \%)$ of labetalol group achieved target blood pressure. After 75 minutes total 24 (96\%) of nifedipine group and 23 (92\%) of labetalol group achieved target blood pressure. One $(4 \%)$ patient of nifedipine group and $2(8 \%)$ patients of labetalol group required cross-over to alternate treatment. Average time required to achieve target blood pressure was not statistically different $(\mathrm{p}$ value $=0.9129 ;>0.05)$.

Table-II: Time required achieving target blood pressure $(n=50)$

\begin{tabular}{|c|c|c|c|c|c|}
\hline $\begin{array}{l}\text { Time } \\
\text { range } \\
\text { (minutes) }\end{array}$ & $\begin{array}{l}\text { GroupA } \\
\text { (Nifedipine } \\
(\%)(n=25)\end{array}$ & $\begin{array}{l}\text { GroupB } \\
\text { (Labetalol) } \\
(\%)(n=25\end{array}$ & $\begin{array}{l}\text { Time } \\
\text { (minutes) } \\
\text { )for group A } \\
\text { (mean } \pm S D)^{\#}\end{array}$ & $\begin{array}{l}\text { Time } \\
\text { (minutes) } \\
\text { for group B } \\
\text { (mean } \pm S D)^{\#}\end{array}$ & $\overline{p \text { value }}$ \\
\hline $0-15$ & $6(24)$ & $4(16)$ & \multirow{4}{*}{$25.63 \pm 10.12$} & \multirow{4}{*}{\multicolumn{2}{|c|}{$30.33 \pm 10.440 .9129^{\text {ns }}$}} \\
\hline $16-30$ & $10(40)$ & $8(32)$ & & & \\
\hline $\begin{array}{l}31-45 \\
46-60\end{array}$ & $\begin{array}{l}6(24) \\
1(4)\end{array}$ & $\begin{array}{l}7(28) \\
3(12)\end{array}$ & & & \\
\hline $61-75$ & $1(4)$ & $1(4)$ & & & \\
\hline
\end{tabular}

\# Student's t -Test, ns= non-significant.

Table III shows secondary outcome variables. There was no maternal and fetal mortality among the two groups. Two (8\%) patients of labetalol group and 1

Table-III: Secondary outcome variables $(\mathrm{n}=50)$

\begin{tabular}{|c|c|c|c|}
\hline \multirow[t]{3}{*}{ Variables } & Group A & Group B & \multirow{2}{*}{ p value } \\
\hline & \multicolumn{2}{|c|}{ (Nifedipine) (Labetalol) } & \\
\hline & (\%) $(n=25)$ & $(\%)(n=25)$ & \\
\hline $\begin{array}{l}\text { Cross-over to alternate } \\
\text { treatment }^{\natural}\end{array}$ & $1(4)$ & $2(8)$ & $1.0^{\text {ns }}$ \\
\hline $\begin{array}{l}\text { Expedited delivery* } \\
\text { Mode of delivery: }\end{array}$ & $17(68)$ & $18(72)$ & $1.0^{\mathrm{ns}}$ \\
\hline Caesarean & $17(68)$ & $14(56)$ & $0.56^{\mathrm{ns}}$ \\
\hline Vaginal & $8(32)$ & $11(44)$ & \\
\hline Maternal ICU admission? & $1(4)$ & $2(8)$ & $1.0^{\mathrm{ns}}$ \\
\hline Neonatal ICU admission? & $3(12)$ & $4(16)$ & $1.0^{\mathrm{ns}}$ \\
\hline Maternal eclampsiaq & $1(4)$ & $3(12)$ & $0.61^{\mathrm{ns}}$ \\
\hline $\begin{array}{l}\text { Decrease in maternal urine } \\
\text { output }{ }^{\text {I }}\end{array}$ & $3(12)$ & $6(24)$ & $0.46^{\mathrm{ns}}$ \\
\hline Maternal heart failure ${ }^{\Uparrow}$ & $1(4)$ & $2(8)$ & $1.0^{\mathrm{ns}}$ \\
\hline Maternal stroke & $0(0)$ & $1(4)$ & $1.0^{\mathrm{ns}}$ \\
\hline $\begin{array}{l}\text { Maternal nausea and } \\
\text { vomiting }\end{array}$ & $2(8)$ & $4(16)$ & $0.67^{\mathrm{ns}}$ \\
\hline $\begin{array}{l}\text { Maternal dizziness and/ } \\
\text { headache }\end{array}$ & $3(12)$ & $6(24)$ & $0.4^{\mathrm{ns}}$ \\
\hline Maternal palpitation & $1(4)$ & $2(8)$ & $1.0^{\mathrm{ns}}$ \\
\hline Fetal heart rate abnormality & $2(8)$ & $1(4)$ & $1.0^{\mathrm{ns}}$ \\
\hline 5 minutes Apgar score $<7^{\pi}$ & $1(4)$ & $3(12)$ & $0.61^{\mathrm{ns}}$ \\
\hline
\end{tabular}

*Chi-square test, Fisher's exact test, ns $=$ non-significant. 
(4\%) patient of nifedipine group required cross-over to alternate treatment $(\mathrm{p}=1.0000 ;>0.05)$. All those required alternate treatment achieved the target blood pressure within 30 minutes. The delivery was expedited in most of the patients of both labetalol (72\%) and nifedipine $(68 \%)$ groups ( $\mathrm{p}$ value $=1.0000 ;>0.05)$. The mode of delivery was also similar $(\mathrm{p}=0.5607 ;>0.05)$. Sixty eight percent of nifedipine group and $56 \%$ patients of labetalol group required caesarean section. Similarly other secondary variables - maternal ICU admission, neonatal ICU admission, maternal eclampsia, decrease in maternal urine output, maternal heart failure, maternal stroke, maternal nausea and vomiting, maternal dizziness and/headache, maternal palpitation, fetal heart rate abnormality, 5 minutes Apgar score $<7$ also showed no statistically significant difference between the groups.

\section{Discussion:}

Severe hypertensive disorders of pregnancy are associated with high rates of maternal and fetal morbidity and mortality. Prompt but smooth control of hypertension should be done using common but safe antihypertensive. The aim of the present study was to compare the effectiveness and tolerability of oral nifedipine and intravenous labetalol in the acute control of severe hypertension of pregnancy.

In the present study, labetalol group had mean maternal age of $26.16 \pm 3.8$ years and nifedipine group had $25.52 \pm 3.5$ years. In the study performed by Dhali B et $\mathrm{al}^{9}$ in India, mean maternal ages were $24.3 \pm 1.2$ years and $23.7 \pm 1.4$ years respectively, comparable to this study. But these were higher in the study performed in Malaysia by Raheem IA et $\mathrm{al}^{3}(32.2 \pm 5.4$ and $31.4 \pm$ 4.1years). As marriage occurs earlier in this subcontinent female becomes mother earlier.

The mean weights of mothers of this study were 56.96 \pm 7.3 kilograms for labetalol group and $56.24 \pm 9.5$ kilograms for nifedipine group. Though these were slightly higher in the study performed by Dhali B et $\mathrm{al}^{9}$ (66.2 \pm 1.1 and $66.6 \pm 1.3$ kilograms).

The mean systolic blood pressures (SBP) of the mothers were comparable among the labetalol (171.08 $\pm 8.1 \mathrm{mmHg})$ and nifedipine $(171.8 \pm 8.4 \mathrm{mmHg})$ groups. Dhali Bet $\mathrm{al}^{9}$ in their study had similar findings (163.2 \pm 1.5 and $163.5 \pm 1.8 \mathrm{mmHg})$. Raheem IA et $\mathrm{al}^{3}$ also mentioned similar findings (170 and $175 \mathrm{mmHg}$ ). The mean diastolic blood pressures (DBP) of the mothers were comparable among the labetalol (112.88 $\pm 8.8 \mathrm{mmHg})$ and nifedipine $(111.24 \pm 5.4 \mathrm{mmHg})$ groups. Dhali B et $\mathrm{al}^{9}$ in their study mentioned similar findings $(110.7 \pm 1.4$ and $111.2 \pm 1.8 \mathrm{mmHg})$. Raheem IA et $\mathrm{al}^{3}$ also mentioned similar findings (108 and 110
$\mathrm{mmHg}$ ). In the present study the mean heart rates of the mothers were comparable among the labetalol $(86.24 \pm$ 10.7 beats $/ \mathrm{min})$ and nifedipine $(86.4 \pm 10.1$ beats $/ \mathrm{min})$ groups. Raheem IA et $\mathrm{al}^{3}$ in their study mentioned similar findings ( $85 \pm 11$ and $90.7 \pm 12$ beats/min).

From above findings it was seen that both labetalol and nifedipine groups had similar baseline characteristicsregarding age, weight, heart rate, systolic and diastolic pressures. So, both were comparable before intervention.

This study showed that average time required to achieve target blood pressure of $\leq 150 / 100 \mathrm{mmHg}$ was $30.33 \pm 10.44$ minutes for labetalol and $25.63 \pm$ 10.12 minutes for nifedipine. After the $5^{\text {th }}$ dose $(75$ minutes) total $23(92 \%)$ of labetalol group and 24 (96\%) of nifedipine group achieved target blood pressure. These findings are comparable. Raheem IA et $\mathrm{al}^{3}$ in their study showed that the median time taken was 30 minutes (interquartile range, IQR 22.5-67.5 minutes) for nifedipine and 45 minutes (IQR 30-60 minutes) for labetalol, but the difference was not significant (if expressed as mean $\pm \mathrm{SD}, 46 \pm 30$ minutes versus $54 \pm 42$ minutes). Similarly, the total number of doses of medication required to achieve target blood pressure was not different. However, Dhali B et $\mathrm{al}^{9}$ showed different findings. Patients received oral nifedipine achieved the goal therapeutic blood pressure more rapidly in $28.2 \pm 11.7$ minutes (mean \pm SD) as compared to $48.4 \pm 23.5$ minutes in those received intravenous labetalol $(\mathrm{p}=0.001 ;<0.05)$. The nifedipine group also required significantly fewer doses $(3.5 \pm 0.5$ vs. $4.5 \pm 1.5)$ to reach the goal blood pressure.

In this study $2(8 \%)$ patients of labetalol group and 1 (4\%) patient of nifedipine group required cross-over to alternate treatment and the alternate treatment achieved the target blood pressure within 30 minutes. In the study performed by Raheem IA et $\mathrm{al}^{3}$. five out of 25 $(20 \%)$ participants in each group required crossover or alternative treatment and all who had crossover treatment achieved target blood pressure within five doses of the crossover regimen. On post hoc analysis the participants initially randomized to nifedipine who then crossed over to labetalol required a shorter time period and fewer doses of drugs after the crossover $(21 \pm 8$ versus $56 \pm 23$ minutes $\mathrm{p}=0.01 ; 1.4 \pm 0.5$ versus $3.75 \pm 1.5$ doses), compared with the participants initially randomized to labetalol and then crossed over to nifedipine. However, Dhali $\mathrm{B}$ et $\mathrm{al}^{9}$ showed both drugs were ultimately effective in reaching the therapeutic goal because there were no failures requiring crossover in either study group.

In the present study delivery of the baby was expedited as soon as blood pressure control was achieved 
groups. Raheem IA et $\mathrm{al}^{3}$ mentioned similar outcomes ( $72 \%$ vs. $64 \%$ ). Fifty six percent patients of labetalol group and $68 \%$ of nifedipine group in this study required caesarean section. Similarly these were $52 \%$ and $64 \%$ according to Raheem IA et $\mathrm{al}^{3}$.

In this study $2(8 \%)$ patients of labetalol group and 1 (4\%) of nifedipine group required ICU admission. Raheem IA et $\mathrm{al}^{3}$ showed 2(8\%) of labetalol group but none of nifedipine group required that. In both studies differences were not significant. Neonatal ICU admission was similar in this study, 4 (16\%) for labetalol group and 3 (12\%) for nifedipine group. Dhali $\mathrm{B}$ et $\mathrm{al}^{9}$ mentioned these were $8 \%$ and $2 \%$. Raheem IA et $\mathrm{al}^{3}$ showed $3(12 \%)$ neonates from each group required ICU admission.

In the present study few patients of both labetalol group (12\%) and nifedipine group (4\%) developed eclampsia. Dhali $\mathrm{B}$ et $\mathrm{al}^{9}$ mentioned that these were $6 \%$ and $2 \%$ respectively. In both studies differences were not significant. Hourly urine output was reduced in 6 (24\%) patients of labetalol group and $3(12 \%)$ of nifedipine group. Dhali $\mathrm{B}$ et $\mathrm{al}^{9}$ mentioned these were $10 \%$ and $4 \%$. Heart failure was developed in $2(8 \%)$ patients of labetalol group and $1(4 \%)$ of nifedipine group in this study. Dhali B et $\mathrm{al}^{9}$ mentioned this was similar $(2 \%)$ in both groups. Only $1(4 \%)$ patient of labetalol group but none of nifedipine group developed stroke. Dhali B et $\mathrm{al}^{9}$ mentioned $4 \%$ patients of labetalol group and $2 \%$ patients of nifedipine group developed stroke, findings were similar.

In this study $16 \%$ patients of labetalol group and $8 \%$ of nifedipine group developed nausea and vomiting. Raheem IA et $\mathrm{al}^{3}$ showed that $16 \%$ patients of labetalol group but none of nifedipine group developed nausea and vomiting. In the present study $24 \%$ patients of labetalol group and $12 \%$ of nifedipine group developed dizziness and/headache. Raheem IA et $\mathrm{al}^{3}$ mentioned it was $12 \%$ in each group. Palpitation was uncommon among both groups- $8 \%$ for labetalol group and $4 \%$ for nifedipine group. It was only $2 \%$ in nifedipine group in the study performed by Raheem IA et $\mathrm{al}^{3}$. In the present study fetal heart rate abnormality was also uncommon$4 \%$ in labetalol group and $8 \%$ in nifedipine group. In the study of Dhali B et $\mathrm{al}^{9}$ these were $6 \%$ and $12 \%$ respectively.

Apgar score was done at birth and 5 minutes thereafter. 5 minutes Apgar score $<7$ was noted in $12 \%$ newborns of labetalol group and $4 \%$ of nifedipine group. In the study of Dhali B et $\mathrm{al}^{9}$ these were $14 \%$ and $6 \%$ respectively.

Outcome variables showed similar findings. This means the differences between the two groups were not statistically significant. A large sample size might give the actual scenario.

\section{Conclusion:}

Pregnancy induced severe hypertension is an obstetric emergency. Early and effective management can prevent morbidity and mortality of both mother and baby. In this study both intravenous labetalol and oral nifedipine were equally effective in reducing maternal blood pressure when used in repeated doses. Both were well tolerated because occurrence of side effects was comparable. Nifedipine may be preferable as it is a simple, flat dose schedule and an oral regimen. Sample size of the study was small and sample was selected purposively. To arrive at a definite conclusion, it is suggested that long term, multicentre, well designed randomized controlled clinical trial with a bigger sample size should be carried out to assess the safety, efficacy and tolerability of labetalol and nifedipine.

\section{Acknowledgements:}

I owe my heartfelt gratitude and indebtedness to Dr. Mahbuba, Professor of Obstetrics and Gynaecology, Sheikh Sayera Khatun Medical College, Gopalgonj for her active help, guidance and valuable suggestions.

\section{References :}

1. Dutta DC. Hypertensive disorders in pregnancy. In: Konar H, editor. Textbook of obstetrics. $7^{\text {th }}$ ed. Kolkata: New Central Book agency (P) Ltd; 2010. p. 219-40.

2. Giannubilo SR, Bezzeccheri V, Cecchi S, Landi B, Battistoni GI, Vitali $P$, et al. Nifedipine versus labetalol in the treatment of hypertensive disorders of pregnancy. Archives of Gynaecology and Obstetrics 2012; 286:637-42.

3. Raheem IA, Saaid R, Omar SZ, Tan PC. Oral nifedipine versus intravenous labetalol acute blood pressure control in hypertensive emergencies of pregnancy: a randomized trial. The Authors BJOG. $2011 ; 10: 1111-18$.

4. National Institute of Health and Clinical Excellence. Hypertension in Pregnancy, The management of hypertensive disorders during pregnancy. Clinical guidelines CG107 Issued: August 2010. Accessible on http://guidance.nice.org.uk/CG107.

5. Magee LA, Cham C, Waterman EJ, Ohlsson A, Dadelszen VP. Hydralazine for treatment of severe hypertension in pregnancy: meta-analysis. BMJ. 2003; 327:955-60.

6. Eschenhagen T. Section III. Modulation of Cardiovascular Function. Treatment of Myocardial Ischemia and Hypertension. In: Brunton LL, Dandan RH, Knollmann BC, editors. Goodman \& Gilman's: The Pharmacological Basis of Therapeutics. 12th ed. San Diego: McGraw Hill Education; 2011.p.271-95.

7. Vermillion ST, Scardo JA, Newman RB, Chauhan SP. A randomized, double-blind trial of oral nifedipine and intravenous labetalol in hypertensive emergencies of pregnancy. Am J Obstet Gynecol. 1999; 181:858-61.

8. Fenakel K, Fenakel G, Appelman Z, Lurie S, Katz Z, Shoham Z. Nifedipine in the treatment of severe preeclampsia. Obstet Gynecol. 1991; 77:331-37.

9. Dhali B, Bhattacharya S, Ganguly RP, Bandyopadhyay S, Mandol M, Dutta M. A randomized trial of intravenous labetalol and oral nifedipine in severe pregnancy induced hypertension. Int J Reprod Contracept Obstet Gynecol. 2012; 1(1):42-46. 